Ondrej Blažo*

doi: $10.5937 /$ spz63-24029

\title{
REFORM OF THE CLEAN VEHICLES DIRECTIVE - FROM PERFORMANCE CRITERIA TO TARGET VALUES ${ }^{* *}$
}

\begin{abstract}
The paper sets the reform of the Clean Vehicles Directive in the broader context of the European environmental policies and inclusion these horizontal policies into public procurement rules. The analysis of effectiveness of that directive is provided from the overall European point of view as well as from the point of view of examples of transposition and different approaches to transposition in the Member States. The Clean Vehicles Directive underwent substantial reform in 2019 which removed case-by-case assessment of environmental impacts of particular vehicles and introduced new approach by setting minimum quantitative criteria for procurement of 'clean' vehicles. Limited scope of the directive aligned to the thresholds of application of the public procurement directives, remained.
\end{abstract}

Keywords: public procurement, EU law, environmental policy, Clean Vehicles Directive.

\section{Introduction - green public procurement as current agenda of the European Union}

Environmental agenda starts to be crucial element of national as well as international policy, visible via rise of environmentally-oriented parties in Europe and activities of civil society. Urgency of impact of deteriorating of life environment and climate change is not only limited to economic sphere, but also can lead to the migration of people, so-called climate refugees (Matuška \& Patakyová, 2018).

It is visible from the agenda of President-elect of the European Commission Ursula von der Leyen that environmental issues will be crucial in European politics when she put 'A European Green Deal' on the first place of her Political Guidelines (Leyen, 2019) and confirming this devotion during her presentation of her team: "I want the European Green Deal to become Europe's hallmark. At the heart of it is our commitment to becoming the world's first climate-neutral continent. It is also a long-term economic imperative: those who act first and fastest will be the ones who grasp the opportunities from the ecological transition. I want Europe to be the front-runner. I want Europe to be the exporter of

\footnotetext{
* Associate Professor at the Faculty of Law of Comenius University in Bratislava, e-mail: ondrej.blazo@flaw. uniba.sk, ORCID: 0000-0001-9721-8724, Web of Science Researcher ID: E-3924-2013.

** The paper was prepared within project APVV-17-0641 "Improvement of effectiveness of legal regulation of public procurement and its application within EU law context".
} 
knowledge, technologies and best practice." (European Commission, 2019b).

Along with the directives and regulations setting limits for pollution, technical standards (Zannoni, 2018a, pp. 1-3), fiscal measures (environmental taxes) or development programmes (for more detail see Zannoni, 2018b), green public procurement can develop into effective vehicle for implementation of environmental consideration into day-to day policy. "Green public procurement encourages public authorities to procure goods and services that have a reduced environmental impact throughout their life cycle when compared to comparable goods and services that would otherwise be procured. The purchasing power of public procurement amounts to approximately $14 \%$ of GDP. A substantial proportion of this money goes to sectors with a high environmental impact such as construction or transport. Therefore, GPP can help to significantly lower the negative impact of public spending on the environment and can help support sustainable innovative businesses"(European Commission, 2019a). Moreover, public procurement is also directly linked with spending of the European Union itself via structural funds and therefore shaping public procurement rules cover both, impact of EU fiscal policy as well as fiscal policy of the Member States (Kováčiková, 2018).

Green procurement (both public and private) can include several factors, objectives and socio-economic goals (Cf. Achillas et al., 2019, p. 40):

1. seeking green/environmentally friendly products or services ('core' green procurement), i.e. products and services that minimize their environmental impact during life cycle (e.g. lower $\mathrm{CO} 2$ and $\mathrm{NOx}$ emissions, decreasing water consumption);

2. focus on social and economic aspects of procurement, i.e. sustainable development;

3. limiting the burden to the environment directly related to policy choices of contracting body;

4. involve and spread a pro-environmental mentality within contracting body, its suppliers as well as general public;

5. support and promote companies that follow eco-friendly criteria as a part of policy.

It must be noted that statutory limits of implementation of green public procurement differentiate private procurement from public procurement. While in the private sector there are no restrictions regarding implementation of green policies, the public bodies shall follow also other statutory duties, seldom directly contradicting to environmental policy. Public body as a contracting authority can contemplate several policy goals, including effective and eco-friendly performance of its own duties, supporting environmental activities of other public bodies and incentive for environmental and human rights consideration of business actors. Environmental dimensions in public procurement can be limited internally as well as externally. Internal limits are stemming from the policy attitude of contracting authority itself and follow ideological, partisan and personal mind set of policy maker. External limits are laid down by local, national and European legislation. European framework of public procurement (PP) is the most visible token of PP rules in Europe.

The Directive on public procurement (Directive 2014/24/EU) is not itself a measure of green public procurement (GPP). In fact, this directive "enables" and "allows" 
GPP under its still strict rules, particularly within technical standards or life-cycle costs where environmental externalities can be included into the calculation.

Environmental requirements and standards may be required as far as they are linked to the subject-matter of the contract (Semple, 2015):

- in relation to technical specification (Art. 21(1) Directive 2014/24/EU)

- in relation to the criteria underlying labels (Art. 43(1)(a) Directive 2014/24/EU)

- in relation to variants (Art. 45(1) Directive 2014/24/EU)

- in relation to selection criteria (Art. 58(1) Directive 2014/24/EU)

- in relation to award criteria (Art. 67(2) Directive 2014/24/EU)

- in relation to contract performance (Art. 70 Directive 2014/24/EU).

Although in general, GPP still remains "optional" or voluntary" and depends on the decision of contracting authority or general policy of a Member State, the EU developed several rules of "mandatory" GPP. Zero-energy plan can serve as an example of mandatory GPP. Under Art. 9(1)(b) of the Energy Performance of Buildings Directive "Member States shall ensure that after 31 December 2018, new buildings occupied and owned by public authorities are nearly zero-energy buildings" (Directive 2010/31/EU). Minimal standards for energy effectiveness of office equipment are enshrined into regulation implementing the Agreement of 20 December 2006 between the Government of the United States of America and the European Community on the coordination of energy-efficiency labelling programmes for office equipment. The "Energy Star" regulation requires contracting authorities to specify energy-efficiency requirements not less demanding than "Common Specifications", i.e. standards for Energy star ecolabel (Art. 7 Regulation No 106/2008).

Similarly, 2009 version of the Clean Vehicles Directive required minimal list of the operational lifetime energy and environmental impacts that shall be considered when purchasing road transport vehicles (Directive 2009/33/EC). However, this approach regarding vehicles was abandoned due to the substantial amendment of the Clean Vehicles Directive and "performance" assessment was replaced by "targeting" of amount of "clean vehicles" (Directive (EU) 2019/1161). This change of the approach to procurement of "clean vehicles" will be analysed further in this paper.

\section{The Clean Vehicles Directive 2009}

Although the full title of the Clean Vehicles Directive 2009 (Directive 2009/33/ EC) was "on the promotion of clean and energy-efficient road transport vehicles", according to Art. 1 it focused only on one means of promotion of "clean vehicles", i.e. via GPP. The Clean Vehicles Directive 2009 saw GPP as purchasing road vehicles "with the objectives of promoting and stimulating the market for clean and energy-efficient vehicles and improving the contribution of the transport sector to the environment, climate and energy policies of the [Union]" (Art. 1 Directive 2009/33/EC). The directive imposed on the Member States duty to require contracting authorities and contracting entities (according to directives on 
public procurement), as well as entities providing public transport services by rail and road due to public service obligations under a public service contract, to take into account the operational lifetime energy and environmental impacts when purchasing road transport vehicles (Art. 3 and Art. 5(1), Directive 2009/33/EC). The restricted subject-matter of the directive is one of its weaknesses, i.e. it is applicable merely on public procurement, which value is not less than thresholds set for the application of public procurement directives (Art. 4 Directive 2014/24/EU). Since this threshold is currently 144.000 euros (Commission Delegated Regulation (EU) 2017/2365) and therefore it is hardly applicable on purchases of single cars and applies on purchases of certain number of cars, or bus or heavy-duty vehicles. Due to these limits, merely $14 \%$ of public purchases of passenger cars in 2009-2015 were covered by the Clean Vehicles Directive comparing to $74.7 \%$ of public purchases of trucks and 43.3\% regarding buses (European Commission, 2017, p. 17). Moreover, the directive did not cover lease, rental and hire-purchase of vehicles, and any contracts for services.

The directive stipulated minimal standards of operational and environmental impacts that shall be taken into consideration: energy consumption; emissions of $\mathrm{CO} 2$; and emissions of NOx, NMHC and particulate matter (Art. 5(2) Directive 2009/33/EC). The Member States may allow involving other operational and environmental impacts for consideration.

Thisminimum-standard technique of harmonization (for methods of harmonisation see e.g. Woods, Watson \& Steiner, 2017) is "implemented" by optional harmonisation method. The operational and environmental impacts can be taken into consideration either (a) by setting technical specifications for energy and environmental performance (or other impacts) in the documentation for the purchase (Art. 5(3)(a) Directive 2009/33/EC), or (b) by including energy and environmental impacts in the purchasing decision (Art. 5(3)

(b) Directive 2009/33/EC). This optional harmonisation appears to be another weakness of the directive. The requirement of setting technical standards in the documentation for the purchase does not seem to be rigorous requirement for "green" procurement because it does not prevent contracting authority from setting environmental and operational criteria too leniently, e.g. merely equal to legal technical standards for motor vehicles. Thus, it is quite easy for a contracting party to fulfil requirements of the Clean Vehicles Directive at least purely formally.

For the inclusion of those impacts into purchasing decision, the Clean Vehicles Directive required to include operational and environmental impacts as criteria for decision (Art. 5(3)(b) Directive 2009/33/EC). On the other hand, the directive did not require any minimum level of weight of these criteria in assessment of respective bids. Moreover, in cases where these impacts are monetised for inclusion in the purchasing decision, the methodology stipulated in the directive shall be used. This methodology is in detail described in Art. 6 of the Clean Vehicles Directive based on fuel consumption (in $\mathrm{MJ}$ ), costs of emission in road transport in euros and lifetime mileage of road transport vehicles (Art. 6, Table 1, 2 and 3 Directive 2009/33/EC).

The Public Procurement included life-cycle costs under Clean Vehicles Directive as mandatory formula if this method of award criteria is included in the procurement 
procedure in question (Art. 68(3) Directive 2014/24/EU). On the other hand, the life-cycle costs calculation was not mandatory for vehicle purchases, in general.

\section{Transposition of the Clean Vehicles Directive 2009}

The Member States were quite reluctant to transpose and only Denmark, Czech Republic and Portugal transposed and notified of transposition within transposition period. The European Commission sent a letter of formal notice to $13 \mathrm{EU}$ Member States due to non-communication of national measures (Belgium, Germany, Spain, Finland, France, Italy, Cyprus, Lithuania, Hungary, Malta, the Netherlands, Poland and Romania), sent the reasoned opinion to 10 Member States (Austria, Bulgaria, Estonia, Greece, Ireland, Luxembourg, Slovenia, Slovakia, Sweden and the United Kingdom) and sent the reasoned opinion as well as referred case to CJ EU regarding Finland (European Commission, 2013, p. 3). The Clean Vehicles Directive provided certain flexibility to the Member States and almost all Member States allowed all options for inclusion operational and environmental impacts. Hence the main responsibility for "greener" public procurement was referred to contracting authorities themselves. These options were restricted by Slovenia, Czech Republic and Sweden. Slovenia exclusively allowed the energy and environmental impacts to be used as award criteria, the Czech Republic did not permit the use of the monetisation option, and Sweden, did not explicitly allow energy and environmental impacts to be used as award criteria (European Commission, 2013, p. 5).

Approaches to transposition of the directive were also different among the Member States - from genuine devotion to the ecological approach to public procurement of road vehicles to quite formal transposition. Belgium developed its own system of scoring vehicles based of "ecoscore" (www.ecoscore.be) that includes environmental and operational impacts in the meaning of the Clean Vehicles Directive (Ministerie de la Region de Bruxelles-Capitale, 2009), as well as noise levels (Art. 1(11) Ministerie de la Region de Bruxelles-Capitale, 2014). Thus, along the Clean Vehicles Directive limits and calculations the "Ecoscore" system involved much more precise and realistic criteria and assessment (Sergeant, Messagie \& Van Mierlo, 2011). Slovakia, on the other hand, literally copied the text of the directive into a separate act (Zákon č.158/2011) whose application is mandatory, however, only in cases when the value of purchase is at least equal to thresholds for application of Public Procurement Directive ( $\$ 45$ Zákon č. 343/2015). These two approaches can be compared on following example: If we take into consideration the most popular cars in Slovakia bought usually by public authorities (Škoda Fabia, Škoda Octavia, Kia Ceed), ecoscore of Škoda Octavia does not exceed 65 (diesel) and 74 (petrol), Škoda Fabia 75 (petrol), Kia Ceed 66 (diesel) and 71 (petrol) (Ecoscore, 2019), comparing the current ecoscore minimum limit for Belgian public purchases is currently 75 (Annex 1, Ministerie de la Region de Bruxelles-Capitale, 2014). Nevertheless, several countries followed such form of transposition, i.e. adoption of separate law copying the text of the directive (e. g. Portugal - Decreto-Lei n.o 140/2010; Romania - Ordonanţa de urgenţă a Guvernului nr. 40/2011). Some countries, on the other hand, included transposition of 
the Clean Vehicles Directive into broader concept of "green" public procurement covering also other products (Art. 106 Ley 2/2011, de 4 de marzo; Art. 4(1)(15) Uredba o zelenem javnem naročanju).

On a basis of data from the period 2009-2015, it is apparent, that in the Europewide context, the inclination towards "clean" vehicles was almost minimal and impact of the Clean Vehicles Directive was definitely limited.

Table 1 (based on data European Commission, 2017, p. 10)

\begin{tabular}{|l|c|c|}
\hline & Petrol/Diesel & $\begin{array}{c}\text { Clean } \\
\text { (low- and zero-emission) }\end{array}$ \\
\hline Passenger cars & $95,3 \%$ & $4,7 \%$ \\
\hline Vans & $99,6 \%$ & $0,4 \%$ \\
\hline Rigid trucks & $99,9 \%$ & $0,07 \%$ \\
\hline Buses & $98,3 \%$ & $1,7 \%$ \\
\hline
\end{tabular}

\section{The Clean Vehicles Directive Reform 2019}

After analysis of the effectiveness of the regime of the Clean Vehicles Directive (European Commission, 2017), in 2019 the amendment of the Clean Vehicles Directive was adopted (Directive (EU) 2019/1161). The legislative technique of this amendment is peculiar: it renamed the original directive to "Directive 2009/33/EC of the European Parliament and of the Council of 23 April 2009 on the promotion of clean road transport vehicles in support of low-emission mobility" (hereinafter also Reformed Clean Vehicles Directive 2019) and replaced text of every article of the original directive by new text. Although the Clean Vehicles Directive 2009 was not repealed or explicitly replaced by new directive, the amendment of 2019 has the same effects. The scope of the Reformed Clean Vehicles Directive 2019 was broadened to purchase, lease, rent or hire-purchase, public service contracts as well as other transport contracts (Art. 1(4) Directive (EU) 2019/1161). However, it still remained linked to thresholds of the Public Procurement Directive.

The reformed directive completely abandoned approach of assessment of operational and environmental impacts as well as life-cost calculation formula replacing them with minimum procurement targets. Under Art. 5 of the Reformed Clean Vehicles Directive, these targets are expressed as minimum percentages of clean vehicles in the total number of road transport vehicles covered by the aggregate of all contracts covered by the directive, awarded between 2 August 2021 and 31 December 2025, for the first reference period, and between 1 January 2026 and 31 December 2030, for the second reference period.

These thresholds were set at different levels for the different Member States because "setting the same requirement for all Member States would risk setting a minimum requirement that could be meaningless for some Member States, but too challenging for others" (European Commission, 2017, p. 37). These thresholds were set on a basis 
of economic capacity of the Member States (GDP) and exposure to pollution (urban population density (Rec. 12 Directive (EU) 2019/1161) and slide form 17,6 \% to 38,5\% regarding light-duty vehicles, $6 \%$ to $15 \%$ for trucks and $29 \%$ to $75 \%$ for buses.

The Reformed Clean Vehicles Directive 2019 provided also time-dynamic definition of clean vehicles. For 2030 the clean vehicles under the directive will be really "clean", since zero CO2 emissions as well as no other pollutant are required for this definition. For 2025 "clean" vehicles can produce certain small amount of CO2 and other pollutant. Moreover, all vehicles using so-called alternative fuels ${ }^{1}$ are also considered clean vehicles.

On the one hand, the previous regime of Clean Vehicles Directive appeared to be truly ineffective. On the other hand, the reformed directive has still several shortcomings. First of all, it still remains stuck to the scope of public procurement directives (Rec. 8 Directive (EU) 2019/1161). Particularly in smaller EU Member States in which it is not necessary to purchase more cars in the same year, effect on light-duty vehicles can be limited. Second, the directive focuses merely on number of vehicles, but not on overall environmental impact of all vehicles covered by the directive, i.e. how "clean" clean vehicles are and what will be environmental exposure of vehicles that are not considered clean. Moreover, thirdly, overall emissions of vehicles during their operational time are not taken into account. Indeed, actual effects of the directive can be assessed in the future due to precise schedule of reports and evaluations stipulated in Art. 10 of the Reformed Clean Vehicles Directive 2019.

\section{European Economic Area and association agreements}

The Reformed Clean Vehicles Directive 2019 was labelled as European Economic Area (EEA) relevant document. The original 2009 directive was included into EEA regime by the decision of the EEA Joint Committee (Art. 1 EEA, 2013) and after fulfilment of constitutional requirements came into force 1 July 2017 within the EEA (EEA, 2018). Therefore, it is possible to apply the whole regime of the 2009 directive also in non-EU countries of the EEA, whereas the regime of 2019 directive is not applicable in the non-EU countries. The Reformed Clean Vehicles Directive 2019 does not provide any thresholds for Norway, Iceland and Liechtenstein. This situation can lead to the following outcomes. First, the EEA Joint Committee does not include the Directive of 2019 into EEA legal regime. Since the directive of 2009 was not repealed but amended, it can remain in force within the EEA regime in the original version. Second, when the EEA Joint Committee includes the directive of 2009 into EEA legal regime, it will become inapplicable for nonEU member states of the EEA.

The situation is similar vis-à-vis associated countries. It was possible for them to approximate to public procurement regime including the Clean Vehicles Directive 2009 however from the Clean Vehicles Directive 2019 they lost their guidance due to the lack of limits for such countries. Nevertheless, the associated countries could still use threshold

\footnotetext{
${ }^{1}$ Electricity, hydrogen, natural gas including biomethane, in gaseous form (compressed natural gas - CNG) and liquefied form (liquefied natural gas - LNG).
} 
given for the EU countries with the closest level of the GDP per capita and urban density as a guidance for approximation in order to gradually fulfil overall environmental targets of the EU for pollution.

\section{Conclusions}

The aim of the EU in environmental policies is obvious: to be an environmental leader of the world. However, setting merely general targets is not a measure precise enough to be achieved. The Clean Vehicles Directive is quite a small stone in the mosaic of environmental measures. On the other hand, under the wording of the Clean Vehicles Directive 2009 it was possible to ignore these environmental goals without violating the directive itself. Some Member States transposed the directive very formally, e.g. by copying the text of the directive it the national legal order, while the others tried to involve strict environmental criteria (e.g. Belgium).

In 2019 this regime was abandoned by setting procurement targets for "clean" vehicles, however, the main shortcoming of this reform is, again, its limited scope aligned to the scope of public procurement directives, ignoring procurement activities under these thresholds. The Reformed Clean Vehicles Directive is less focused on the terms and conditions within the public procurement, so it is less a "public procurement" directive. Using "green" targets, it lays down criteria for general policies of the Member States that shall achieve certain amounts of eco-friendly vehicles in public sector. Since it is still quite easy to circumvent the directive, environmental goals still mainly remain the responsibility of the Member States, and the real impact of the directive depends on its transposition. The Reformed Clean Vehicles Directive does not provide any guidelines for transposition and paths for achievement of the goals. It possible that some states rely on the "old" system of setting criteria under Clean Vehicles Directive 2009, which can provide one of the options to achieve envisaged targets. However, the specific character of the directive stemming from the method of harmonization (more precisely, the directive does not harmonize laws of the Member States at all) can also cause that it will be quite difficult to assess proper transposition of the directive before the target dates. Failure to fulfil duties of a Member State will have irreparable consequences at the due date of achievement of target values. Thus, infringement can hardly lead to fulfilment of the goals of the directive - clean transportation. Therefore, proper transposition and implementation of the Reformed Clean Vehicles Directive is one of the environmental challenges of the Member States, as well as the new von der Leyen's European Commission.

\section{References}

Achillas, C. et al. 2019. Green Supply Chain Management. Abington/Oxford/New York: Routledge. Kováčiková, H. 2018. Verejné obstarávanie ako problematický aspekt čerpania štrukturálnych fondov. In: Právo fondov EÚ v teórii a praxi. Bratislava: Úrad 
podpredsedu vlády pre investície a informatizáciu Slovenskej republiky, pp. 76-85. Semple, A. 2015. The link to the subject matter: a glass ceiling for sustainable public contracts?. In: Sjafjell, B. \& Wiesbrock, A. (eds). Sustainable Public Procurement Under EU Law. Cambridge University Press, pp. 50-74. doi: 10.1017/cbo9781316423288.005.

Woods, L., Watson, P. \& Steiner, J. 2017. Harmonisation. In: Steiner \& Woods EU Law. Oxford: Oxford University Press, pp. 323-343.

Zannoni, D. 2018a. Balancing market needs and environmental protection: Vehicle approval in the European Union. Maastricht Journal of European and Comparative Law, XX(X), pp. 1-16. doi: 10.1177/1023263X18794409.

Zannoni, D. 2018b. Fiscal State Aid to Promote Clean Transport. EC Tax Review, 5, pp. 250-259.

\section{Legal sources}

EEA. 2013. Decision of the EEA Joint Committee No 173/2013 of 8 October 2013 amending Annex XX (Environment) to the EEA Agreement. EEA: OJ L 58, 27.2.2014, p. 27-27. Available at: https://eur-lex.europa.eu/eli/dec/2013/173(2)/oj.

EEA. 2018. Decisions of the EEA Joint Committee for which the constitutional requirements under Article 103 of the EEA Agreement have been fulfilled and related Decisions. EEA: OJ C 97, 15.3.2018, p. 3-7.

Directive 2009/33/EC of the European Parliament and of the Council of 23 April 2009 on the promotion of clean and energy-efficient road transport vehicles. European Union: OJ L 153, 18.6.2010, p. 13-35.

Directive 2010/31/EU of the European Parliament and of the Council of 19 May 2010 on the energy performance of buildings. European Union: OJ L 153, 18.6.2010, p. 13-35.

Directive 2014/24/EU of the European Parliament and of the Council of 26 February 2014 on public procurement and repealing Directive 2004/18/EC. European Union: OJ L 94, 28.3.2014, p. 65-242. Available at: http://eur-lex.europa.eu/legal-content/ $\mathrm{EN} / \mathrm{TXT} /$ ?uri=celex:32014L0024.

Directive (EU) 2019/1161 of the European Parliament and of the Council of 20 June 2019 amending Directive 2009/33/EC on the promotion of clean and energy-efficient road transport vehicles. European Union: OJ L 188, 12.7.2019, p. 116-130.

Regulation No 106/2008 of the European parliament and of the Council of 15 January 2008 on a Community energy-efficiency labelling programme for office equipment. European Union: OJ L 39, 13.2.2008, p. 1-7.

Commission Delegated Regulation (EU) 2017/2365 of 18 December 2017 amending Directive 2014/24/EU of the European Parliament and of the Council in respect of the application thresholds for the procedures for the award of contracts. European Union: OJ L 337, 19.12.2017, p. 19-20. Available at: https://eur-lex.europa.eu/ legal-content/EN/TXT/?uri=celex:32017R2365.

European Commission. 2013. Report from the Commission to the European Parliament, the Council, the European Economic and Social Committee and the Committee of the Regions on the application of Directive 2009/33/EC on the promotion of clean and energy efficient road transport vehicle. Available at: http://eur-lex.europa. 
eu/LexUriServ/LexUriServ.do?uri=OJ:L:2009:120:0005:0012:en:pdf (accessed: 10 November 2019).

European Commission. 2017. Commission Staff Working Document Impact Assessment Accompanying the document Proposal for A Directive of the European Parliament and of theCouncilamendingDirective2009/33/EConthepromotion of cleanandenergy-efficient road transport vehicles SWD/2. Available at: https://eur-lex.europa.eu/legal-content/EN/ TXT/HTML/?uri=CELEX:52017SC0366\&qid=1573401400667\&from=EN.

European Commission. 2019a. Environmental Implementation Review 2019: Policy Background. Available at: http://ec.europa.eu/environment/eir/pdf/eir_2019_ policy_background.pdf.

European Commission. 2019b. The von der Leyen Commission: for a Union that strives for more. IP/19/5542. Available at: https://ec.europa.eu/commission/presscorner/ detail/en/ip_19_5542.

Ministerie de la Region de Bruxelles-Capitale. 2009. Arrêté du Gouvernement de la Région de Bruxelles-Capitale relatif à l'introduction de véhicules plus respectueux de l'environnement dans les flottes des autorités régionales. Belgium. Available at: http://www.etaamb.be/fr/arrete-du-gouvernement-de-la-region-de-bruxellescapit_ n2009031360.html.

Ministerie de la Region de Bruxelles-Capitale. 2014. Arrêté du Gouvernement de la Région de Bruxelles-Capitale relatif à l'exemplarité des pouvoirs publics en matière de transport et modifiant larrêté du Gouvernement de la Région de Bruxelles-Capitale du 7 avril 2011 relatif aux plans de déplacem. Belgium. Available at: http://www.etaamb.be/fr/ arrete-du-gouvernement-de-la-region-de-bruxellescapit_n2014031529.html.

Decreto-Lei n. ${ }^{\circ}$ 140/2010. Diário da República n. ${ }^{\circ}$ 251/2010, Série I de 2010-12-29. Available at: https://data.dre.pt/eli/dec-lei/140/2010/12/29/p/dre/pt/html.

Ordonanţa de urgenţă a Guvernului nr. 40/2011 privind promovarea vehiculelor de transport rutier nepoluante şi eficiente din punct de vedere energetic. Romania: Monitorul Oficial al României, 307.

Zákon č.158/2011 Z.z. o podpore energeticky a environmentálne úsporných motorových vozidiel a o zmene a doplnení niektorých zákonov [Act No 158/2011 On the promotion of energy-saving and environmentally friendly motor vehicles and on the amendment of other laws]. Available at: https://www.slov-lex.sk/static/ pdf/2011/158/ZZ_2011_158_20120301.pdf.

Zákon č. 343/2015 Z.z. o verejnom obstarávaní a o zmene a doplnení niektorých zákonov [Act No. 343/2015 on public procurement and amendment of certain other laws]. Available at: https://www.slov-lex.sk/static/pdf/2015/343/ ZZ_2015_343_20190901.pdf.

Uredba o zelenem javnem naročanju [Decree on green public procurement], Uradni list $R S$, št. 51/17 in 64/19. Available at: http://pisrs.si/Pis.web/ pregledPredpisa?id=URED7202.

Ley 2/2011, de 4 de marzo, de Economía Sostenible, BOE núm. 55, de 05/03/2011. Available at: https://www.boe.es/eli/es/1/2011/03/04/2/con.

Von der Leyen, U. 2019. A Union that strives for more. My agenda for Europe. Political 
Guidelines for the Next European Commission 2019-2024. Available at: https:// ec.europa.eu/commission/sites/beta-political/files/political-guidelines-nextcommission_en.pdf.

\section{Website references}

Ecoscore. 2019. Available at: www.ecoscore.be (Accessed: 10 November 2019).

Matuška, P. \& Patakyová, M.T. 2018. Klimatickí utečenci a ich právne postavenie v kontexte medzinárodného práva verejného a práva Európskej únie [Climate refugees and their legal status in the context of international public law and the European Union law]. Societas et Iurisprudentia, 6(4), pp. 76-96. [online] http://sei.iuridica.truni. sk/archive/2018/04/SOCIETAS-ET-IURISPRUDENTIA-2018-04.pdf

Sergeant, N., Messagie, M. \& Van Mierlo, J. 2011. CLEAN VEHICLES EUROPE versus ECOSCORE. Analysis and comparison of website and methodology. Study accomplished under the authority of the Flemish, Walloon and Brussels Capital Region. Available at: www.ecoscore.be (Accessed: 10 November 2019). 


\title{
Dr Ondrej Blažo
}

Docent, Pravni fakultet, Comenius univerzitet, Bratislava, Slovačka

e-mail: ondrej.blazo@flaw.uniba.sk

ORCID: 0000-0001-9721-8724

Web of Science Researcher ID: E-3924-2013.

\section{REFORMA DIREKTIVE O ČISTIM VOZILIMA (CLEAN VEHICLES DIRECTIVE) - OD KRITERIJUMA USPEŠNOSTI DO CILJANIH VREDNOSTI}

\author{
Sažetak
}

Rad postavlja reformu Direktive o čistim vozilima (Clean Vehicles Directive) u širi kontekst evropske politike zaštite životne sredine i uključivanje ovih horizontalnih politika u pravila o javnim nabavkama. Analiza efikasnosti direktive se sprovodi sa opšteg aspekta EU, kao i sa aspekta primera i različitih pristupa primene/transpozicije ovih pravila u državama članicama. Direktiva je prošla kroz značajnu reformu 2019. godine, koja je uklonila kazuističku procenu ekološkog uticaja konkretnih vozila i uvela novi pristup postavljajući minimalne kvantitativne kriterijume za nabavku „čistih“ vozila. Ograničen domen primene ove direktive usklađen sa pragovima primene direktiva o javnim nabavkama i dalje ostaje.

Ključne reči: javna nabavka, pravo EU, politika zašite životne sredine, Direktiva o čistim vozilima (Clean Vehicles Directive).

Article history:

Received: 15 November 2019

Accepted: 27 January 2020 